\title{
Cis-Segregation of c.1171C>T Stop Codon (p.R391*) in SERPINC1 Gene and c.1691G>A Transition (p.R506Q) in F5 Gene and Selected GWAS Multilocus Approach in Inherited Thrombophilia
}

\author{
Donato Gemmati ${ }^{1,2,3, *}$, Giovanna Longo ${ }^{1}\left(\mathbb{D}\right.$, Eugenia Franchini ${ }^{2}$, Juliana Araujo Silva ${ }^{1}(0)$, Ines Gallo ${ }^{1}$, \\ Barbara Lunghi ${ }^{4}$, Stefano Moratelli ${ }^{2}$, Iva Maestri ${ }^{5}$, Maria Luisa Serino ${ }^{2,5}$ and Veronica Tisato ${ }^{3,6}$ \\ 1 Department of Translational Medicine, University of Ferrara, 44121 Ferrara, Italy; \\ giovanna.longo@unife.it (G.L.); juliana.silva@unife.it (J.A.S.); ines.gallo@unife.it (I.G.) \\ 2 Centre Haemostasis \& Thrombosis, University of Ferrara, 44121 Ferrara, Italy; \\ eugenia.franchini@unife.it (E.F.); stefanomoratelli@libero.it (S.M.); maria.luisa.serino@unife.it (M.L.S.) \\ 3 University Center for Studies on Gender Medicine, University of Ferrara, 44121 Ferrara, Italy; \\ veronica.tisato@unife.it \\ 4 Department of Life Sciences and Biotechnology, University of Ferrara, 44121 Ferrara, Italy; \\ barbara.lunghi@unife.it \\ 5 Department of Medical Sciences, University of Ferrara, 44121 Ferrara, Italy; iva.maestri@unife.it \\ 6 Department of Translational Medicine and LTTA Centre, University of Ferrara, 44121 Ferrara, Italy \\ check for
} updates

Citation: Gemmati, D.; Longo, G.; Franchini, E.; Araujo Silva, J.; Gallo, I.; Lunghi, B.; Moratelli, S.; Maestri, I.; Serino, M.L.; Tisato, V. Cis-Segregation of c.1171C $>$ T Stop Codon (p.R391*) in SERPINC1 Gene and c.1691G>A Transition (p.R506Q) in $F 5$ Gene and Selected GWAS Multilocus Approach in Inherited Thrombophilia. Genes 2021, 12, 934. https://doi.org/10.3390/genes 12060934

Academic Editor: Dorottya Csuka

Received: 11 May 2021

Accepted: 15 June 2021

Published: 18 June 2021

Publisher's Note: MDPI stays neutral with regard to jurisdictional claims in published maps and institutional affiliations.

Copyright: () 2021 by the authors. Licensee MDPI, Basel, Switzerland. This article is an open access article distributed under the terms and conditions of the Creative Commons Attribution (CC BY) license (https:// creativecommons.org/licenses/by/ $4.0 /)$.

\begin{abstract}
Inherited thrombophilia (e.g., venous thromboembolism, VTE) is due to rare loss-offunction mutations in anticoagulant factors genes (i.e., SERPINC1, PROC, PROS1), common gainof-function mutations in procoagulant factors genes (i.e., F5, F2), and acquired risk conditions. Genome Wide Association Studies (GWAS) recently recognized several genes associated with VTE though gene defects may unpredictably remain asymptomatic, so calculating the individual genetic predisposition is a challenging task. We investigated a large family with severe, recurrent, earlyonset VTE in which two sisters experienced VTE during pregnancies characterized by a perinatal in-utero thrombosis in the newborn and a life-saving pregnancy-interruption because of massive VTE, respectively. A nonsense mutation (CGA > TGA) generating a premature stop-codon (c.1171C $>$ T; p.R391*) in the exon 6 of SERPINC1 gene (1q25.1) causing Antithrombin (AT) deficiency and the common missense mutation (c.1691G>A; p.R506Q) in the exon 10 of $F 5$ gene (1q24.2) (i.e., FV Leiden; rs6025) were coinherited in all the symptomatic members investigated suspecting a cis-segregation further confirmed by STR-linkage-analyses [i.e., SERPINC1 IVS5 (ATT) 5-18, F5 IVS2 (AT) 6-33 $_{3}$ and F5 IVS11 (GT) ${ }_{12-16}$ ] and SERPINC1 intragenic variants (i.e., rs5878 and rs677). A multilocus investigation of blood-coagulation balance genes detected the coexistence of FV Leiden (rs6025) in trans with FV HR2-haplotype (p.H1299R; rs1800595) in the aborted fetus, and F11 rs2289252, F12 rs1801020, F13A1 rs5985, and KNG1 rs710446 in the newborn and other members. Common selected gene variants may strongly synergize with less common mutations tuning potential life-threatening conditions when combined with rare severest mutations. Merging classic and newly GWAS-identified gene markers in at risk families is mandatory for VTE risk estimation in the clinical practice, avoiding partial risk score evaluation in unrecognized at risk patients.
\end{abstract}

Keywords: SERPINC1; F5; FV Leiden; GWAS; cis-segregation; crossing-over; inherited thrombophilia

\section{Introduction}

Inherited thrombophilia is considered a polygenic and multifactorial disease, where rare and common inherited prothrombotic defects combine with acquired/transient risk factors to finely tune disease penetrance, age of onset, and severity [1-8]. It is defined as a disorder of blood coagulation characterized by a tendency for thrombus formation in veins or arteries mainly due to anomalies in blood composition, blood flow, or vascular 
wall. Thrombophilia is often used to address venous thromboembolism (VTE) including deep vein thrombosis (DVT) and pulmonary embolism (PE). It is a common disease, characterized by an annual incidence of 1-3 patients per 1000 per year [9]. VTE has a mean case-fatality rate of $6.4 \%$ after a first VTE event being twice for PE (9.7\%) than for DVT (4.6\%) [9]. Both sexes are equally affected by a first VTE event, though males have more than 2-fold higher risk for recurrence and this has been considered in the past as a paradox also accounting for genetics and X- or Y-linked mutations within genes with sex-specific effects as for other complex diseases [10-14]. As research and knowledge in complex disease improve, novel risk factors can be identified, and new tests become available. Accordingly, to better predict the risk of VTE in carrier subjects, multilocus genetic risk score approaches based on Genome Wide Association Studies (GWAS) have been generated $[15,16]$. In the last few years, GWAS have made a massive effort in recognizing several common gene variants and low-penetrance gene variants (often Single Nucleotide Polymorphisms, SNPs), sometimes identifying unsuspected genes as contributors to the VTE global genetic risk score (GRS) [15-17]. Apart from coagulation and anticoagulation genes, platelets and other blood cells genes (e.g., those of the immune system cells) are also involved in inherited thrombophilia. GWAS, especially in exome (WES), and Transcriptome Wide Association Studies (TWAS) must be considered for a targeted and complete GRS assessment [18].

Among the acquired circumstantial conditions for VTE, pregnancy, hormone therapy, cancer, bone fractures, and immobilization are the strongest risk factors [19]. Since the heritability of VTE is over $60 \%$, together with the classical rare gene defects of the natural anticoagulants (i.e., SERPINC1, PROC, PROS1), the conventional recognized risk models are based on the commonest prothrombotic mutations [20,21]. Accordingly, also considering the common F5 (Factor V Leiden, c.1691G>A; rs6025) and F2 (Prothrombin, c.20210G >A; rs1799963) gene defects, the approach only partially accounts for the high VTE incidence [21], suggesting that the risk assessment could be strongly improved including additional gene markers $[20,22]$ to progress the guide for clinical geneticists in the management of inherited thrombophilia [21]. This approach should also be considered in a sex-oriented perspective due to the specific acquired and circumstantial risk situations the different sexes experience lifelong [23].

The SERPINC1 gene (locus 1q25.1) spans over $13 \mathrm{~kb}$ and contains 7 exons encoding for the antithrombin (AT) serine protease inhibitor [24]. AT plays a crucial role as natural anticoagulant within the blood coagulation cascade, exerting its role mainly by inhibiting the serine protease thrombin (Factor IIa) and the activated factor X (FXa). SERPINC1 gene defects are considered the strongest inherited risk factors for VTE so that AT homozygous deficiency causes embryonic death and the combination of different SERPINC1 mutations or variants is responsible for the recently fascinating described genotype-phenotype gradient, that is, the clinical variability found among carriers of the same or different combination of SERPINC1 defects [25-27]. The evidence that SERPINC1 gene is poorly polymorphic underlies its high susceptibility even to minor changes in nucleotide sequence responsible for loss of function mutations and strong structural and functional changes, leading to severe thrombosis [28]. AT deficiency is indeed a rare thrombotic defect increasing the risk of thrombosis up to 10-folds in heterozygous carriers [24,29].

The F5 gene (locus 1q24.2) encodes for coagulation FV, it spans about $75 \mathrm{~kb}$ and contains 25 exons [30]. FV has a two-faced role within the blood coagulation, acting either as procoagulant factor when it is activated (FVa) by thrombin (FIIa) or as an anticoagulant molecule after cleavage by activated protein C (APC) causing the loss of its procoagulant property. Accordingly, mutations in F5 gene may result either in hemorrhagic or thrombotic clinical phenotypes [30]. The most common inherited prothrombotic defect is a mutation in F5 gene (c.1691G>A; rs6025), responsible for the APC-resistance phenotype, better known as FV Leiden (p.R506Q) [31,32]. The presence of F5 c.1691A allele increases the risk of thrombosis of about 6-folds in heterozygous carriers and up to 80-folds in homozygotes [30]. In addition, particular haplotypes in F5 gene [33] can be present in trans with the mutated F5 c.1691A, affecting in those heterozygous subjects the anticoagulant side of the FV 
protein guaranteed by the normal F5 c.1691G allelic counterpart, this due to a reduction in the expression of the normal FV allele (e.g., HR2; c.4070A>G, p.H1299R; rs1800595) [34] or to a complete absence of the normal FV allele expression (e.g., c.5279A>G; p.Y1702C; rs118203907) [35]. These not-so-rare conditions exacerbate in turn the prothrombotic clinical phenotype accomplished by the mutated F5 c.1691A allele as in the condition known as pseudo-homozygous APC-resistance [36-38]. Finally, the F5 gene also contributes to arterial thrombosis as demonstrated in a study aimed at exploring the relationship between F5 gene variants and the occurrence of coronary artery disease [39].

Rare loss of function mutations in SERPINC1 gene and the common F5 c.1691G>A mutation can be coinherited in the same individual leading to a strong increase in the associated VTE risk [1-3]. In addition, SERPINC1 and F5 genes map closely in the same region of chromosome 1 and this might allow the combined defect to co-segregate in cis exacerbating severity and penetrance of inherited thrombophilia [1-3].

Here, we report a multilocus genetic risk investigation in a large family carrying in cis a combined FV Leiden and SERPINC1 gene defect with high penetrance, early onset, and severe phenotypes, including severe DVT in two sisters during pregnancy characterized by a perinatal in utero unusual thrombotic event and a massive DVT, respectively, in spite of prophylactic antithrombotic therapy.

\section{Material and Methods}

\subsection{Family and Study Design}

The family investigated in this report belongs to a previously described Italian family [2] whose members have now been enrolled in a local project entitled "Multilocus Genetic Scores predictive for Venous Thromboembolism Risk (MaGiSTER): real life evaluation and validation in a cohort of VTE patients" aimed at scoring the VTE risk modification within the thrombophilic family characterized by well-established gene defects. The previous report did not recognize in the family the main gene defect(s) and did not perform a sequence analysis of the SERPINC1 gene but just reported a phenotypic assessment of AT antigen and activity levels, and did not implement an investigation through a multilocus genetic approach nor evaluate any worsening of the clinical phenotypes. As far as the MaGiSTER study is concerned, it was approved by the local IRB (code number 242/2020) according to the Declaration of Helsinki and all the members of the investigated family signed informed consent at the time of the blood drawn.

\subsection{DNA Extraction, PCR Conditions, and Sequencing}

Whole blood was collected from the family members and frozen at $-80{ }^{\circ} \mathrm{C}$. DNA was isolated from thawed whole blood by the automated DNA extraction and purification robot (BioRobot EZ1 System QIAGEN; Hilden, Germany).

SERPINC1 full-length gene amplicons were obtained by PCR of specific fragments including promoter, exons and exon-intron junctions by PCR-mediated direct sequencing by using the BigDye Terminator v1.1 Cycle Sequencing Kit and ABI Prism 310 Genetic Analyzer (Applied Biosystems, Waltham, MA, USA) according to previous reports [40].

The multilocus-genetic approach, including $A B O$ rs8176719; F2 rs1799963; F5 rs6025; F5 rs4524; F5 rs1800595; F11 rs2289252; F11 rs2036914; F12 rs1801020; F13A1 rs5985; SERPINE10 rs2232698; SERPINC1 rs121909548; FGG rs2066865; and KNG1 rs710446, was selected from previous informative multilocus studies on the prediction of the thrombotic risk [20,22,41]. Genotyping for each SNP was performed by rhAmp ${ }^{\circledR}$ SNP Assay (IDT, Integrated DNA Technologies, Coralville, IA, USA) on QuantStudio ${ }^{\text {TM }}$ 3-Real-Time PCR System (Thermo Fisher Scientific, Waltham, MA, USA) according to the supplier's instructions. Within each run, DNA samples with a known genotype were used as internal control references. 


\subsection{STRs Linkage Analyses}

The sequence primers for PCR amplification of SERPINC1 IVS5 STR (ATT) $5-18$ were as follows: P1(Fw): 5'-TGA AGC CTG AGA ATG AAT TAT CAG-3'; P2(Rev): 5'-AGA GTG GGG AAG GTG TAC TC-3'; and P3(Rev): $5^{\prime}$-CCA CTG CAC TCC AGC CTG GG-3'. The $\mathrm{P} 3$ primer was 6-FAM labelled at $5^{\prime}$ end. PCR amplification was performed in a total volume of $50 \mu \mathrm{L}$ by using P1 and P2 (first PCR), and P1 and P3 (nested PCR), according to previous reports [42].

The sequence primers for PCR amplification of $F 5$ IVS2 STR (AT) $)_{6-33}$ were as follows: P1(Fw): 5'- GAT TGC TTG AGG CCA GGA GTT-3'; P2(Rev): 5'-TTG TCC TAA ATG ACC CTC TTG C- $3^{\prime}$. The P1 primer was 6-FAM labelled at $5^{\prime}$ end. PCR amplification was performed in a total volume of $50 \mu \mathrm{L}$ according to previous reports [43].

The sequence primers for PCR amplification of F5 IVS11 STR (GT) $12-16$ were as follows: P1(Fw): 5'-GTG GGT GAC ATC ATA GC-3'; P2(Rev): 5'-TGA CAT GGA CTA TAA CAC-3'. The P1 primer was 6-FAM labelled at $5^{\prime}$ end. PCR amplification was performed in a total volume of $50 \mu \mathrm{L}$ according to previous reports [44].

Primers and FAM labeling were from IDT (Integrated DNA Technologies, Coralville, IA, USA), TopTaq DNA polymerase was from Qiagen LLC (Germantown, MD, USA) and all the PCR amplifications were performed on an Agilent SureCycler 8800 system (Santa Clara, CA, USA) according to the supplier's instructions.

By Denaturing Capillary Electrophoresis Analysis, one-tenth of each FAM-labelled PCR amplicon was diluted in HD-Formamide solution and GeneScan 500ROX Size Standard (Applied Biosystems, Thermo Fisher Scientific, Waltham, MA, USA). The samples were run on ABI Prism 310 Genetic Analyzer Instrument and analysed by GeneMapper ${ }^{\circledR}$ Software 5.0 (Applied Biosystems, Thermo Fisher Scientific, Waltham, MA, USA). Within each run, DNA samples with known genotype were used as internal control references.

\subsection{Restriction Analyses}

By using the same couples of primers as in the sequence analyses, two common SNPs were further investigated to complete family linkage studies. The c.1011A $>G$ (p.Q337Q) synonymous variant (rs5878) within the SERPINC1 exon 5 detectable by PstI restriction analysis (NEB, Ipswich, MA, USA) common among Caucasians (ALFA Allele Frequency: $\mathrm{A}=0.64 ; \mathrm{G}=0.36$ ) and the g.14956C $>\mathrm{G}$ variant (rs677) within SERPINC1 intron 6-7 detectable by DdeI restriction analysis (NEB, Ipswich, MA, USA) (ALFA Allele Frequency: $C=0.87 ; G=0.13$ ). Restriction analyses were performed according to the supplier's instructions.

\section{Results}

\subsection{Family History and Index Cases}

Figure 1a shows the original large family tree characterized by a relapsing of severe thrombotic and thrombophlebitis episodes at young age. Ten members belonging to the first generation had thrombotic manifestations with seven of them characterized by type-1 AT deficiency (AT level 45-50\%; normal range, 70-125\%). Thrombotic manifestations among the subsequent generations were clinically reported only within two branches of the family, and one of these was previously published as characterized by the coexistence of the type-1 AT deficiency and FV Leiden combined defect (dashed frame in Figure 1a) [2]. 
a

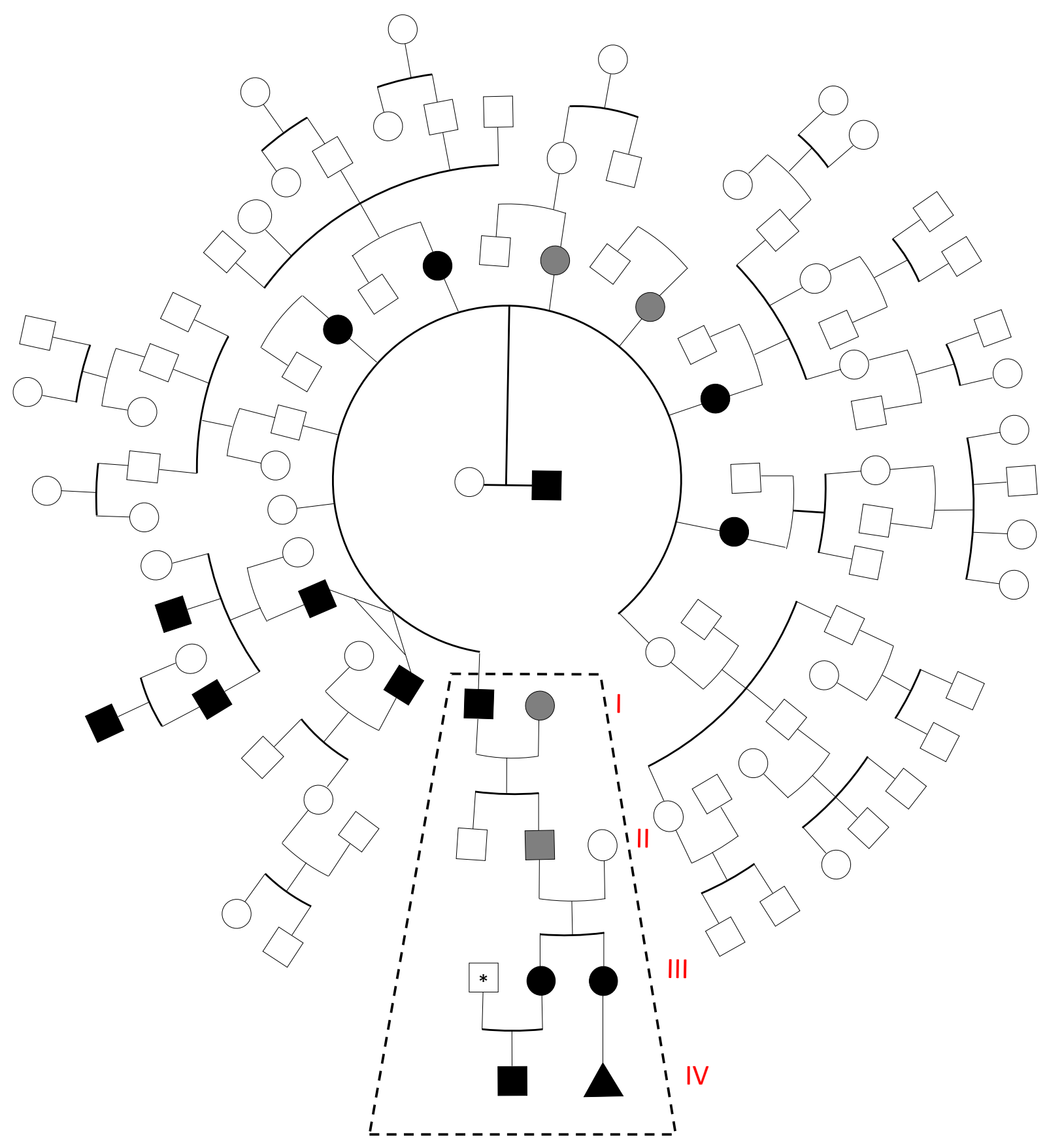

Figure 1. Cont. 


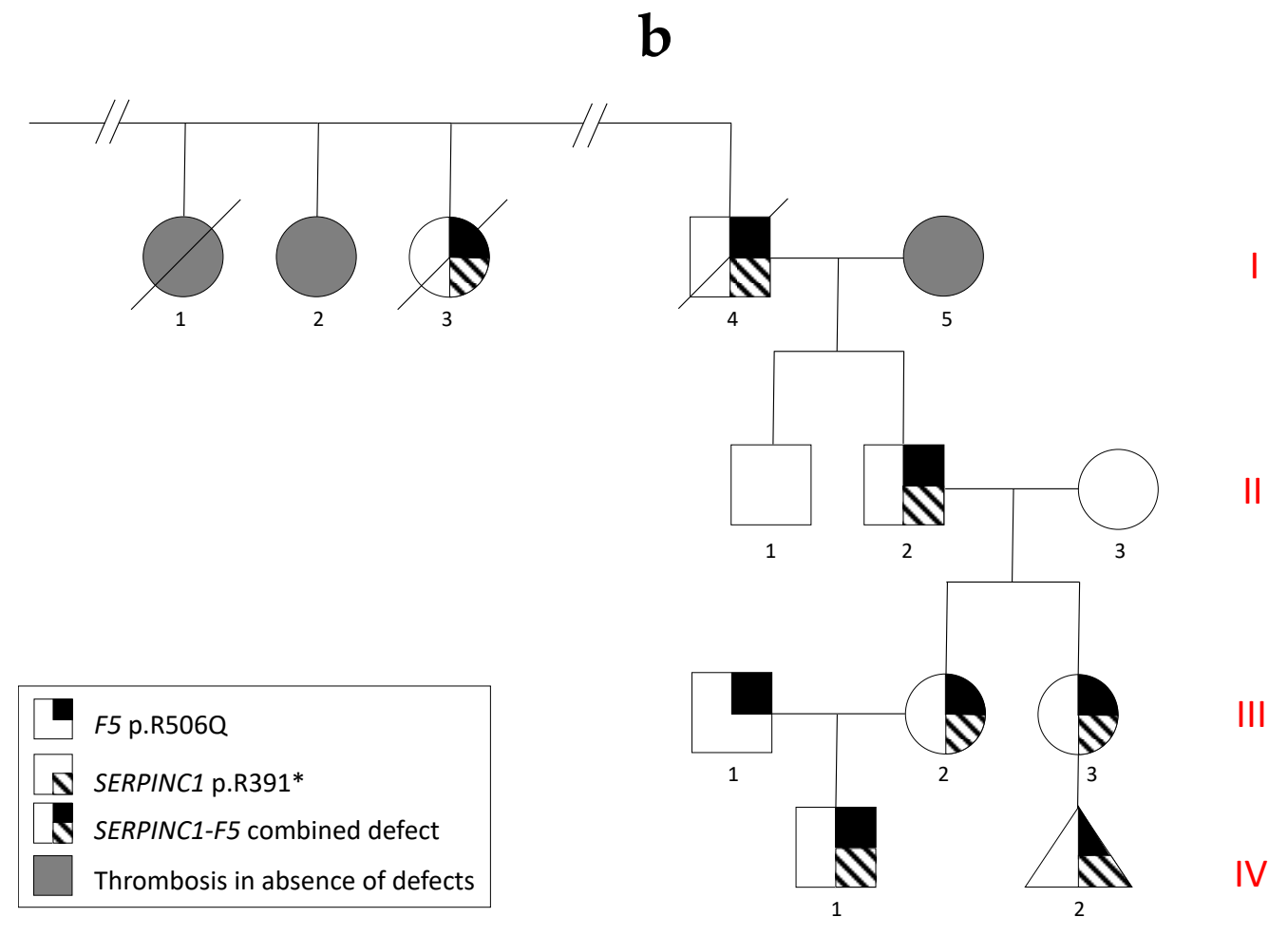

Figure 1. (a) Full pedigree of the original family. Black symbols refer to thrombotic subjects carrying the combined AT-FV Leiden defect (i.e., SERPINC1-F5 mutations). Grey symbols refer to thrombotic subjects in the absence of any identified defect. The asterisk indicates an asymptomatic carrier of a single F5 p.R506Q defect. The triangle symbol indicates aborted fetus. Dashed frame indicates subfamily described in Figure 1b. (b). Extended pedigree of the previous investigated family [2]. This is part of the full pedigree shown in Figure 1a (dashed frame). The different symbols are specified in figure legend (bottom left of the figure). The triangle symbol indicates aborted fetus. Strike-through symbols indicate dead individuals.

Figure $1 \mathrm{~b}$ shows an extended family tree of the previously described family, in that report the propositus (I3) and her brother (I4) had their first DVT episode at the age of 20 and 21 years, respectively, characterized by following mixed arterial and venous (I3) and venous (I4) relapses in the presence of the combined AT-FV Leiden defect. Interestingly, although no prothrombotic defects were detected, additional members of the family had thrombotic manifestations: spontaneous DVT at age of 47 with relapse (I1), DVT after surgery at age of 45 (I2), and recurrent thrombophlebitis (I5). With regard to subject II2, at the age of 14 years, he had his first DVT after surgery and despite anticoagulant therapy he relapsed at the age of 20, experiencing bilateral DVT and successive saphenectomy. Moreover, his two daughters (III2 and III3), asymptomatic at the time of the first investigation [2], subsequently developed severe DVT episodes. At the age of 28 years, the first daughter (III2) during her first pregnancy (23 weeks of gestation) had DVT and afterward underwent full heparin treatment. Her son (IV1) developed severe perinatal vein renal thrombosis during the first week after birth and a further deep instrumental investigation confirmed the in utero origin of the renal thrombosis. At the age of 8 years, the second daughter (III3), in the absence of concomitant risk conditions had her first DVT and at the age of 15 years she developed abdominal aorta thrombosis. After two previous spontaneous miscarriages, at the age of 23 years, she had a massive VTE and a transient ischemic accident (TIA) during the last pregnancy. This complex thrombotic condition required premature life-saving pregnancy-interruption at 8 weeks of gestation, despite heparin treatment and negative results for autoantibody investigations [45]. To summarize, the AT-FV Leiden combined defect was detected in the following thrombotic subjects (i.e., I3, I4, II2, III2, III3, IV1). A laboratory screening in subject III1detected FV Leiden in heterozygous condition and this could better explain the severe in utero/perinatal thrombosis in the son (IV1), potentially 
at risk to be FV Leiden homozygotes in the presence of AT deficiency. Child IV1 was under heparin treatment until 18 months; he is now 4 years-old, and he did not inherit both FV Leiden alleles from his parents showing an AT-FV Leiden combined defect in heterozygous condition. He is now on lifelong oral anticoagulant therapy while his father is up to now completely asymptomatic.

The combined AT-FV Leiden defect was also indirectly detected in the aborted tissue (IV2) only by molecular analysis of DNA extracted from paraffin-embedded material (see below).

\subsection{Genetic Analyses}

In the affected members of the family, we detected a combined defect due to a type-1 AT deficiency caused by a previously described c.1171C $>$ T mutation (CGA > TGA) in the exon 6 of SERPINC1 gene causing a premature stop codon at arginine 391 (p.R391*) [28] and the common FV Leiden mutation due to an arginine-to-glutamine change at codon 506 (p.R506Q) in the exon 10 of $F 5$ gene.

Table 1 shows the list of the SNPs investigated and the genotyping results in the members of the family presented in Figure 1b. The carrier condition of the minor allele (i.e., hetero/homozygosis) for each SNP is shown in bold regardless it is considered the risk-allele and the reported ALFA frequency (Allele Frequency Aggregator; https: //www.ncbi.nlm.nih.gov/snp/docs/gsr/alfa/, accessed on 12 June 2021) is shown in brackets (see MAF).

Table 1. Genotyping on selected SNPs in the members of Family $1 \mathrm{~b}$.

\begin{tabular}{|c|c|c|c|c|c|c|c|c|c|c|c|c|}
\hline \multirow{2}{*}{ Ch. } & \multirow{2}{*}{ Gene } & \multirow{2}{*}{$\begin{array}{c}\text { Change } \\
(n t)\end{array}$} & \multirow{2}{*}{ MAF } & \multirow{2}{*}{ Variant } & \multirow{2}{*}{$\begin{array}{c}\text { Change } \\
\text { (aa) }\end{array}$} & \multicolumn{7}{|c|}{ Family $1 b$} \\
\hline & & & & & & II2 & II3 & III1 & III2 & III3 & IV1 & IV2 \\
\hline 9 & $\begin{array}{c}A B O \\
\text { rs } 8176719\end{array}$ & $-/ \mathrm{G}$ & $\begin{array}{c}\mathrm{G} \\
(0.379)\end{array}$ & c.261delG & - & $-/-$ & $-1-$ & $-1-$ & $-1-$ & $-/-$ & $-/-$ & $-1-$ \\
\hline 11 & $\begin{array}{c}F 2 \\
\text { rs1799963 }\end{array}$ & $\mathrm{G}>\mathrm{A}$ & $\begin{array}{c}\mathrm{A} \\
(0.0135)\end{array}$ & $3^{\prime}$ UTR & - & GG & GG & GG & GG & GG & GG & GG \\
\hline 1 & $\begin{array}{c}F 5 \\
\text { rs } 6025\end{array}$ & $G>A$ & $\begin{array}{c}\mathrm{A} \\
(0.025)\end{array}$ & Missense & R506Q & GA & GG & GA & GA & GA & GA & GA \\
\hline 1 & $\begin{array}{c}F 5 \\
\text { rs1800595 }\end{array}$ & $A>G$ & $\begin{array}{c}G \\
(0.0485)\end{array}$ & Missense & H1299R & $\mathrm{AA}$ & $\mathrm{AA}$ & $\mathrm{AA}$ & $\mathrm{AA}$ & $\mathrm{AA}$ & AA & AG \\
\hline 1 & $\begin{array}{c}F 5 \\
\text { rs } 4524\end{array}$ & $\mathrm{~T}>\mathrm{C}$ & $\begin{array}{c}C \\
(0.267)\end{array}$ & Missense & K830R & $\mathrm{TC}$ & TT & $\mathrm{TT}$ & TT & TT & TT & $\mathrm{TC}$ \\
\hline 4 & $\begin{array}{c}F 11 \\
\text { rs2289252 }\end{array}$ & $G>A$ & $\begin{array}{c}\text { A } \\
(0.399)\end{array}$ & Intron & - & $\mathbf{A A}$ & $\mathbf{A A}$ & AG & AA & $\mathbf{A A}$ & AA & AA \\
\hline 4 & $\begin{array}{c}F 11 \\
\text { rs2036914 }\end{array}$ & $G>A$ & $\begin{array}{c}\text { A } \\
(0.479)\end{array}$ & Intron & - & GG & GG & GA & GG & GG & GG & GG \\
\hline 5 & $\begin{array}{c}F 12 \\
\text { rs1801020 }\end{array}$ & $\mathrm{G}>\mathrm{A}$ & $\begin{array}{c}\text { A } \\
(0.237)\end{array}$ & $5^{\prime}$ UTR & - & GG & GA & GA & GA & GA & GA & GA \\
\hline 6 & $\begin{array}{l}F 13 A 1 \\
\text { rs5985 }\end{array}$ & $\mathrm{G}>\mathrm{T}$ & $\begin{array}{c}\mathrm{T} \\
(0.243)\end{array}$ & Missense & V34L & GG & $\mathrm{GT}$ & GG & GT & GT & GT & GT \\
\hline 1 & $\begin{array}{l}\text { SERPINE10 } \\
\text { rs2232698 }\end{array}$ & $G>A$ & $\begin{array}{c}\mathrm{A} \\
(0.0077)\end{array}$ & $\begin{array}{c}\text { Stop } \\
\text { Gained }\end{array}$ & $\mathrm{R} 67^{*}$ & GG & GG & GG & GG & GG & GG & GG \\
\hline 1 & $\begin{array}{l}\text { SERPINC1 } \\
\text { rs121909548 }\end{array}$ & $G>T$ & $\begin{array}{c}\mathrm{T} \\
(0.0015)\end{array}$ & Missense & A384S & GG & GG & GG & GG & GG & GG & GG \\
\hline 4 & $\begin{array}{c}F G G \\
\text { rs2066865 }\end{array}$ & $\mathrm{C}>\mathrm{T}$ & $\begin{array}{c}\mathrm{T} \\
(0.23)\end{array}$ & $\begin{array}{c}\text { near } \\
3^{\prime} \text { UTR }\end{array}$ & - & $\mathrm{CC}$ & CC & $\mathrm{CC}$ & CC & $\mathrm{CC}$ & $\mathrm{CC}$ & $\mathrm{CC}$ \\
\hline 3 & $\begin{array}{c}\text { KNG1 } \\
\text { rs710446 }\end{array}$ & $\mathrm{T}>\mathrm{C}$ & $\begin{array}{c}C \\
(0.419)\end{array}$ & Missense & I581T & $\mathrm{TC}$ & $\mathrm{TC}$ & $\mathrm{TT}$ & $\mathrm{CC}$ & $\mathrm{TC}$ & TC & $\mathrm{TC}$ \\
\hline
\end{tabular}

Ch.: Chromosome; MAF: Minor Allele Frequency; G/G or - /G: likely to have blood type A or B; -/-: likely to have blood type O; the asterisk $\left(^{*}\right)$ : indicates a translation termination codon (gained stop codon). The minor allele is shown in bold. 
As regards the two sisters (III2 and III3), who experienced severely complicated pregnancy outcomes, apart from the combined SERPINC1-F5 defect, they both were homozygous for $F 11$ rs2289252, heterozygous for $F 12$ rs1801020 and F13A1 rs5985, and carried KNG1 rs710446 in homozygous and heterozygous conditions, respectively.

As regards child IV1, who experienced the perinatal renal thrombosis and the aborted fetus IV2, apart from the combined SERPINC1-F5 defect, they both carried F12 rs1801020, F13A1 rs5985 and KNG1 rs710446 in heterozygous and F11 rs2289252 in homozygous condition. In addition, the aborted fetus was diagnosed as a female by means of sexspecific PCR fragments (X/-, - /Y, and X/Y), and she carried F5 HR2 rs1800595 in trans with $F 5$ Leiden rs6025 almost certainly inherited from her father (not shown in the figure and not available for the analysis). Unexpectedly, subject III1 carried isolated heterozygous F5 p.R506Q mutation with a 50\% chance of transmission to his son at risk to inherit one F5 p.506Q-allele from both parents, then becoming a severely affected QQ-homozygotes in combination with the SERPINC1 mutation. As explained above, this dramatic condition did not occur.

\subsection{Family Linkage Analysis}

In all the members of the investigated family carrying the type- 1 AT deficiency, the SERPINC1 c.1171C>T stop codon (p.R391*) segregated with the c.1011A-allele of the synonymous p.Q337Q variant (rs5878), the g.14956C-allele variant (rs677), and the STR IVS5 (ATT) ${ }_{12}$ repeat in the SERPINC1 gene (Figure 2, Table 2). The highly polymorphic trinucleotide STR yielded different heterozygous status in every affected member, allowing us to undoubtedly recognize the mutated SERPINC1 allele along with the four generations.
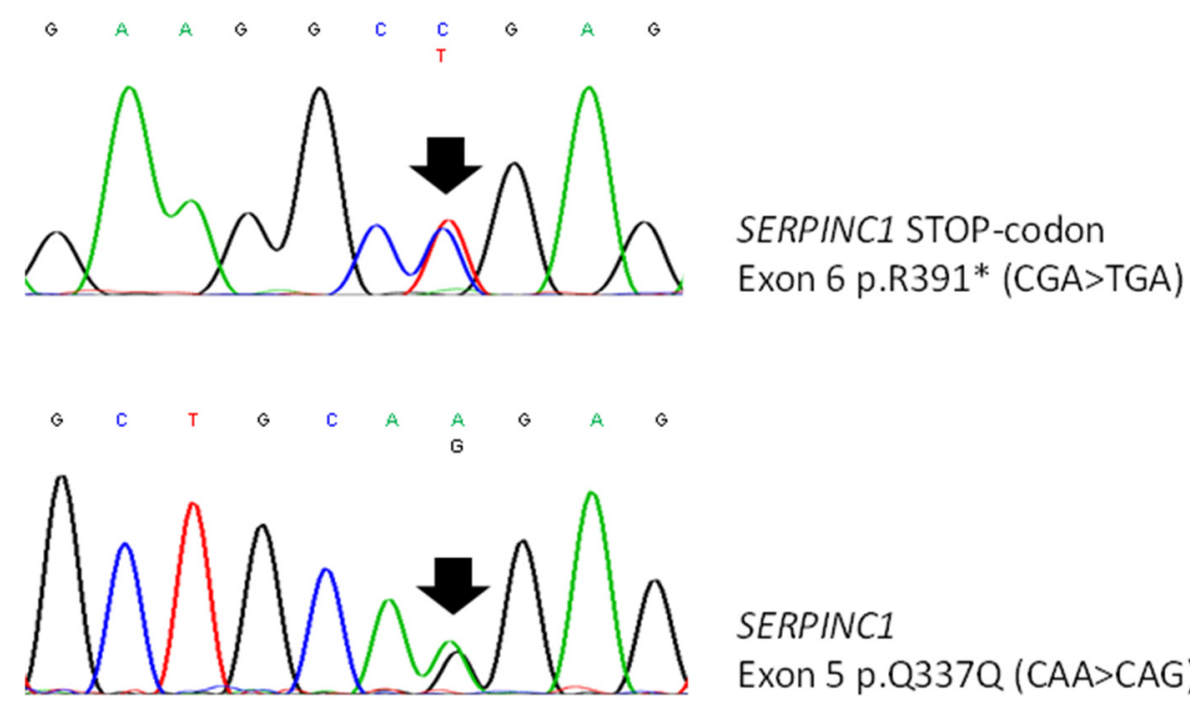

SERPINC1

Exon 5 p.Q337Q (CAA>CAG)

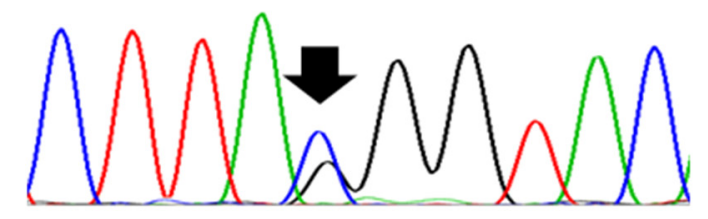

SERPINC1

IVS 6/7 Variant $(C>G)$

Figure 2. Sequence analysis of SERPINC1 gene showing: p.R391* STOP-codon (upper panel); p.Q337Q synonymous variant (middle panel); intronic (IVS 6-7) C > G variant (rs677) (lower panel). 
Table 2. Haplotyping in the members of Family $1 b$.

\begin{tabular}{|c|c|c|c|c|c|c|c|c|}
\hline \multirow{2}{*}{ Gene } & \multirow{2}{*}{ Variation } & \multicolumn{7}{|c|}{ Family $1 b$} \\
\hline & & II2 & II3 & III1 & III2 & III3 & IV1 & IV2 \\
\hline SERPINC1 & c. $1171 C>T($ p.R391*) & $\mathrm{CT}$ & $\mathrm{CC}$ & $\mathrm{CC}$ & $\mathrm{CT}$ & $\mathrm{CT}$ & $\mathrm{CT}$ & $\mathrm{CT}$ \\
\hline SERPINC1 & $\begin{array}{c}\text { c.1011A }>\text { G (p.Q337Q) } \\
\text { rs5878 }\end{array}$ & AA & AG & AG & AG & AG & AG & AG \\
\hline SERPINC1 & $($ rs677) $C>G$ & CG & CG & GG & CG & CG & CG & CG \\
\hline SERPINC1 & IVS5 (ATT) $)_{5-18}$ & $10 / \mathbf{1 2}$ & $11 / 13$ & $10 / 11$ & $11 / \mathbf{1 2}$ & $11 / \mathbf{1 2}$ & $10 / \mathbf{1 2}$ & nd \\
\hline F5 & c.1691A>G (p.R506Q) & AG & AA & AG & AG & AG & AG & AG \\
\hline$F 5$ & IVS2 $(\mathrm{AT})_{6-33}$ & $15 / \mathbf{1 7}$ & $15 / 19$ & $16 / 20$ & $17 / 19$ & $17 / 19$ & $16 / 19$ & nd \\
\hline F5 & IVS11 (GT) $)_{12-16}$ & $14 / 15$ & $13 / 15$ & $13 / 14$ & $13 / 14$ & $13 / 14$ & $13 / 14$ & $14 / 14$ \\
\hline
\end{tabular}

nd: not determined due to shortage of genetic material from aborted sample (IV2). Mutated alleles, or those in linkage with the defect(s), are shown in bold.

Among FV Leiden carriers, subject II2 and his two daughters (III2 and III3) carried the F5 IVS2 (AT) 17 allele, and undoubtedly inherited from their mother (II3) the normal (AT) 19 allele. On the contrary, child IV1 appeared to have inherited the FV Leiden allele from his carrier father (III1) suspecting an intragenic crossing-over event that cannot be confirmed by our investigation.

Finally, the known strong linkage between FV Leiden mutation and the F5 IVS11 $(G T)_{14}$ repeat allowed us to easily discriminate the normal F5 counterpart allele in each subject along with the four generations (Table 2).

\section{Discussion}

Inherited thrombophilia is a multifactorial disorder in which genetic predispositions together with circumstantial risk factors interact to develop the clinical phenotype; therefore, acquired and genetic risk factors may often coexist in the same patient. Defects in the SERPINC1 gene, responsible for AT deficiency, are considered the strongest inherited VTE risk factors, and the associated VTE incidence rate is about $1 \%$ per year among subjects carrying the single gene defect [46]. On the other hand, the coexistence of additional inherited or acquired risk predispositions synergistically increases the risk up to 10-20 fold, which is greater than the sum of their single risks.

It has been described that the mean onset age of the first VTE event among patients carrying a single SERPINC1 gene defect is higher than that of patients carrying two or more thrombotic defects, and this is particularly evident among patients belonging to the same family $[1,2,46]$. Of particular interest is the coexistence of SERPINC1 and FV Leiden defects in the same patient, characterized by two distinct familial inheritance patterns. In detail, both genes closely map on chromosome 1 (i.e., F5, 1q24.2, g.169.511.954169.586.531 and SERPINC1, 1q25, g.173.903.804-173.917.378), and their gene defects can be either in the same (cis) or in separate (trans) copy of chromosome 1. In this study, the cosegregation in cis of the two defects (i.e., F5, c.1691G $>$ A; SERPINC1, c.1171C $>$ T) leads to the highest penetrance of familial thrombophilia and could be rarely terminated by recombinant events because of their relative short distance (g.169.549.811 and g.173.907.497 respectively). Moreover, it has been recently described an intriguing genotype-phenotype gradient of the clinical phenotype, accounting for the wide variability found among carriers of SERPINC1 combined defects [27]. This concept could indeed also be extended to the coexistence of additional defects in different genes $[20,22,41]$, which is the rationale of the polygenic nature of inherited thrombophilia and is part of the proposed MaGiSTER Study. Accordingly, the accumulation of mild unknown prothrombotic factors identifiable by GWAS might also be present in cases with a more severe clinical phenotype and contribute to the final individual risk. 
During the drawing of the present manuscript, exhaustive counselling with the members of the presented family ascribed the severest clinical phenotype to subfamily $1 b$, mainly characterized by DVT during pregnancy in the two sisters despite a prophylactic full heparin treatment in which the younger also had several previous spontaneous miscarriages. Consistent with this synopsis, there is also the perinatal renal thrombosis in the fetus of the older sister.

A multilocus genetic approach, by selecting those SNPs previously shown to be significantly associated with thrombosis and/or with pregnancy-related thrombosis in GWAS or large multicenter studies, could reveal if additional molecular markers had a role in this peculiar clinical finding [47-51].

Interestingly, F12 rs1801020, described as associated with circulating coagulation FXII levels and with arterial or venous thrombosis [52], was found in a heterozygous condition both in the two sisters and in their offspring (newborn and aborted fetus). A similar condition was detected for further at-risk genotypes marked as F11 rs2289252 and rs2036914, associated with circulating coagulation FXI levels and with antenatal and pregnancy-related thrombosis $[47,53,54]$ as well as KNG1 rs710446, associated with in vitro coagulation test (aPTT) variability and with venous thrombosis [54].

Altogether, the above genes coding for proteins belonging to the High Molecular Weight Kininogen/Prekallikrein/FXI/FXII contact system, have a key role in blood coagulation balance and their defects are not associated with bleeding but rather with venous or arterial thrombosis and recurrent pregnancy loss also affecting fetal-placental unit as demonstrated by previous GWAS and case-control studies [52-54]. Although this is in line with their physiological role in regulating important vascular activities as vasodilatation and modulation of thrombus formation by anti-coagulant, anti-aggregant, and pro-fibrinolytic properties [55,56], large meta-analyses and GWAS revealed weak or null associations with thrombosis or cardiovascular diseases $[57,58]$.

Particular consideration should be taken into account for F5 gene, not only for its closeness with SERPINC1 gene, allowing in the present family the coinheritance in cis of both defects, but also for the presence of additional at-risk SNPs within the F5 gene that may modify the overall individual risk. As regards $F 5$ rs4524, the minor allele $(\mathrm{T}>\mathrm{C})$ has been described as protective from VTE in non-carriers of Factor V Leiden (rs6025) [59]. In addition, rs4524 has been consistently associated with VTE in three large control-case studies (i.e., LETS, "Leiden Thrombophilia" study; MEGA-1 and MEGA-2, "Multiple Environmental and Genetic Assessment of Risk Factors for Venous Thrombosis" study) also after adjustment for FV Leiden, being the two variants in low linkage disequilibrium $\left(r^{2}=0.02\right)[48,49]$. As regards F5 rs1800595, also known as FV HR2, the minor allele (A > G) is associated to decreased coagulation FV levels and the coinheritance with FV Leiden increases the VTE risk of about 10-15 fold and decrease the age of the first thrombotic events of about six years [34-36]. Moreover, infant renal thrombosis associated with F5 rs6025 was previously reported, though a not satisfactory genetic investigation was performed [60]. We finally detected in the two sisters and in the new-born the at risk rs4524 genotype while in the aborted tissue the rs4524 and FV HR2 heterozygous conditions could have seriously worsened the already compromised coagulative balance as previously described $[37,61]$.

\section{Conclusions}

The present study highlights that the coexistence of selected at-risk gene variants might contribute to the exact assessment of the individual thrombotic risk. The risk that severest genetic combinations might occur during generations needs to be properly considered and assessed also in families with well-established and identified genetic defects. In the OMIC era, the novel recognized genetic and acquired risk factors for thrombosis and pregnancy related complications [62-66] strongly prompt towards translational real-life applications, proposing that merging classic and newly GWAS- and/or TWAS-identified markers and circulating biomarkers in selected at risk populations is mandatory for a 
complete, personalized and sex-related risk assessment [12] to avoid partial risk score estimations in unrecognized at-risk patients.

Author Contributions: Conceptualization, D.G. and V.T.; Data curation, G.L., E.F., J.A.S., B.L., I.G., S.M., I.M. and M.L.S.; Formal analysis, S.M. and M.L.S.; Funding acquisition, D.G. and V.T.; Investigation, D.G.; Methodology, G.L., E.F., J.A.S., B.L., I.G., S.M., I.M. and M.L.S.; Supervision, D.G. and V.T.; Writing—original draft, D.G. and V.T.; Writing—review and editing, D.G. and V.T. All authors have read and agreed to the published version of the manuscript.

Funding: This work was supported by local University of Ferrara Grants (V.T.: FAR2058191 and FIR1900522; D.G.: FAR2037748, FAR1918975 and FAR1825303).

Institutional Review Board Statement: The study was conducted according to the guidelines of the Declaration of Helsinki, and approved by the local Institutional Review Board (code number 242/2020; date of approval 22 July 2020).

Informed Consent Statement: Informed consent was obtained from all subjects involved in the study.

Data Availability Statement: All relevant data are included in the manuscript.

Conflicts of Interest: The authors declare no conflict of interest.

\section{References}

1. Van Boven, H.H.; Reitsma, P.H.; Rosendaal, F.R.; Bayston, T.A.; Chowdhury, V.; Bauer, K.A.; Scharrer, I.; Conard, J.; Lane, D.A. Factor V Leiden (FV R506Q) in families with inherited antithrombin deficiency. Thromb. Haemost. 1996, 75, 417-421. [CrossRef]

2. Gemmati, D.; Serino, M.L.; Moratelli, S.; Mari, R.; Ballerini, G.; Scapoli, G.L. Coexistence of antithrombin deficiency, factor V Leiden and hyperhomocysteinemia in a thrombotic family. Blood Coagul. Fibrinolysis 1998, 9, 173-176. [CrossRef]

3. Ordonez, A.; de Cos, C.; Minano, A.; Rodriguez, J.; Hernandez-Espinosa, D.; Munoz, J.A.; Gonzalez-Conejero, R.; Vicente, V.; Corral, J. Coexistence of three genetic risk factors in a Spanish thrombophilic family: Factor V Leiden, prothrombin 20210 and a new type I antithrombin deficiency. Thromb. Haemost. 2007, 97, 153-155. [CrossRef] [PubMed]

4. Gemmati, D.; Serino, M.L.; Tognazzo, S.; Ongaro, A.; Moratelli, S.; Gilli, G.; Forini, E.; De Mattei, M.; Scapoli, G.L. The reduced sensitivity of the ProC Global test in protein S deficient subjects reflects a reduction in the associated thrombotic risk. Blood Coagul. Fibrinolysis 2001, 12, 691-697. [CrossRef] [PubMed]

5. Gemmati, D.; Serino, M.L.; Moratelli, S.; Tognazzo, S.; Ongaro, A.; Scapoli, G.L. Coexistence of factor V G1691A and factor II G20210A gene mutations in a thrombotic family is associated with recurrence and early onset of venous thrombosis. Haemostasis 2001, 31, 99-105. [CrossRef] [PubMed]

6. Gemmati, D.; Serino, M.L.; Scapoli, G.L. A modified functional global test to measure protein C, protein S activities and the activated protein C-resistance phenotype. Thromb. Res. 1998, 92, 141-148. [CrossRef]

7. Gemmati, D.; Serino, M.L.; Verzola, I.; Mari, R.; Moratelli, S.; Ballerini, G. Resistance to activated protein C and low levels of protein S activity in nine thrombophilic families: A correct diagnosis. Blood Coagul. Fibrinolysis 1997, 8, 118-123. [CrossRef]

8. Gemmati, D.; Serino, M.L.; Mari, R.; Verzola, I.; Moratelli, S.; Ballerini, G. Different Anticoagulant Response to Activated Protein C (APC test) and to Agkistrodon Contortix Venom (ACV test) in a Family with FV-R506Q Substitution. Clin. Appl. Thromb. Hemost. 1997, 3, 168-173. [CrossRef]

9. Naess, I.A.; Christiansen, S.C.; Romundstad, P.; Cannegieter, S.C.; Rosendaal, F.R.; Hammerstrom, J. Incidence and mortality of venous thrombosis: A population-based study. J. Thromb. Haemost. 2007, 5, 692-699. [CrossRef]

10. Douketis, J.; Tosetto, A.; Marcucci, M.; Baglin, T.; Cosmi, B.; Cushman, M.; Kyrle, P.; Poli, D.; Tait, R.C.; Iorio, A. Risk of recurrence after venous thromboembolism in men and women: Patient level meta-analysis. BMJ 2011, 342, d813. [CrossRef]

11. Roach, R.E.; Lijfering, W.M.; Rosendaal, F.R.; Cannegieter, S.C.; le Cessie, S. Sex difference in risk of second but not of first venous thrombosis: Paradox explained. Circulation 2014, 129, 51-56. [CrossRef]

12. Gemmati, D.; Varani, K.; Bramanti, B.; Piva, R.; Bonaccorsi, G.; Trentini, A.; Manfrinato, M.C.; Tisato, V.; Care, A.; Bellini, T. "Bridging the Gap" Everything that Could Have Been Avoided If We Had Applied Gender Medicine, Pharmacogenetics and Personalized Medicine in the Gender-Omics and Sex-Omics Era. Int. J. Mol. Sci. 2019, 21, 296. [CrossRef]

13. Singh, A.V.; Subhashree, L.; Milani, P.; Gemmati, D.; Zamboni, P. Interplay of iron metallobiology, metalloproteinases, and FXIII, and role of their gene variants in venous leg ulcer. Int. J. Low Extrem. Wounds 2010, 9, 166-179. [CrossRef]

14. Singh, A.V.; Vyas, V.; Montani, E.; Cartelli, D.; Parazzoli, D.; Oldani, A.; Zeri, G.; Orioli, E.; Gemmati, D.; Zamboni, P. Investigation of in vitro cytotoxicity of the redox state of ionic iron in neuroblastoma cells. J. Neurosci. Rural Pract. 2012, 3, 301-310. [CrossRef] [PubMed]

15. Morange, P.E.; Tregouet, D.A. Lessons from genome-wide association studies in venous thrombosis. J. Thromb. Haemost. 2011, 9 (Suppl. 1), 258-264. [CrossRef] [PubMed] 
16. Tang, W.; Teichert, M.; Chasman, D.I.; Heit, J.A.; Morange, P.E.; Li, G.; Pankratz, N.; Leebeek, F.W.; Pare, G.; de Andrade, M.; et al. A genome-wide association study for venous thromboembolism: The extended cohorts for heart and aging research in genomic epidemiology (CHARGE) consortium. Genet Epidemiol. 2013, 37, 512-521. [CrossRef] [PubMed]

17. de Haan, H.G.; van Hylckama Vlieg, A.; Germain, M.; Baglin, T.P.; Deleuze, J.-F.; Trégouët, D.-A.; Rosendaal, F.R. Genome-wide association study identifies a novel genetic risk factor for recurrent venous thrombosis. Circ. Genom. Precis. Med. 2018, 11, e001827. [CrossRef]

18. Zoller, B.; Svensson, P.J.; Dahlback, B.; Lind-Hallden, C.; Hallden, C.; Elf, J. Genetic risk factors for venous thromboembolism. Expert Rev. Hematol. 2020, 13, 971-981. [CrossRef] [PubMed]

19. Prandoni, P. Acquired risk factors for venous thromboembolism in medical patients. Hematol. Am. Soc. Hematol. Educ. Program. 2005. [CrossRef]

20. Soria, J.M.; Morange, P.E.; Vila, J.; Souto, J.C.; Moyano, M.; Tregouet, D.A.; Mateo, J.; Saut, N.; Salas, E.; Elosua, R. Multilocus genetic risk scores for venous thromboembolism risk assessment. J. Am. Hearth Assoc. 2014, 3, e001060. [CrossRef]

21. Varga, E.A.; Kujovich, J.L. Management of inherited thrombophilia: Guide for genetics professionals. Clin. Genet. 2012, 81, 7-17. [CrossRef]

22. Hlatky, M.A.; Greenland, P.; Arnett, D.K.; Ballantyne, C.M.; Criqui, M.H.; Elkind, M.S.; Go, A.S.; Harrell, F.E., Jr.; Hong, Y.; Howard, B.V.; et al. Criteria for evaluation of novel markers of cardiovascular risk: A scientific statement from the American Heart Association. Circulation 2009, 119, 2408-2416. [CrossRef]

23. McRae, S.; Tran, H.; Schulman, S.; Ginsberg, J.; Kearon, C. Effect of patient's sex on risk of recurrent venous thromboembolism: A meta-analysis. Lancet 2006, 368, 371-378. [CrossRef]

24. Corral, J.; de la Morena-Barrio, M.E.; Vicente, V. The genetics of antithrombin. Thromb. Res. 2018, 169, 23-29. [CrossRef] [PubMed]

25. Lane, D.A.; Mannucci, P.M.; Bauer, K.A.; Bertina, R.M.; Bochkov, N.P.; Boulyjenkov, V.; Chandy, M.; Dahlback, B.; Ginter, E.K.; Miletich, J.P.; et al. Inherited thrombophilia: Part 2. Thromb. Haemost. 1996, 76, 824-834. [PubMed]

26. Lane, D.A.; Mannucci, P.M.; Bauer, K.A.; Bertina, R.M.; Bochkov, N.P.; Boulyjenkov, V.; Chandy, M.; Dahlback, B.; Ginter, E.K.; Miletich, J.P.; et al. Inherited thrombophilia: Part 1. Thromb. Haemost. 1996, 76, 651-662. [PubMed]

27. Bravo-Perez, C.; de la Morena-Barrio, M.E.; Palomo, A.; Entrena, L.; de la Morena-Barrio, B.; Padilla, J.; Minano, A.; Navarro, E.; Cifuentes, R.; Corral, J.; et al. Genotype-phenotype gradient of SERPINC1 variants in a single family reveals a severe compound antithrombin deficiency in a dead embryo. Br. J. Haematol. 2020, 191, e32-e35. [CrossRef]

28. Chowdhury, V.; Olds, R.J.; Lane, D.A.; Conard, J.; Pabinger, I.; Ryan, K.; Bauer, K.A.; Bhavnani, M.; Abildgaard, U.; Finazzi, G.; et al. Identification of nine novel mutations in type I antithrombin deficiency by heteroduplex screening. Br. J. Haematol. 1993, 84, 656-661. [CrossRef]

29. Castaldo, G.; Cerbone, A.M.; Guida, A.; Tandurella, I.; Ingino, R.; Tufano, A.; Ceglia, C.; Di Minno, M.N.; Ruocco, A.L.; Di Minno, G. Molecular analysis and genotype-phenotype correlation in patients with antithrombin deficiency from Southern Italy. Thromb. Haemost. 2012, 107, 673-680. [CrossRef]

30. Duga, S.; Asselta, R.; Tenchini, M.L. Coagulation factor V. Int. J. Biochem. Cell Biol. 2004, 36, 1393-1399. [CrossRef]

31. Bertina, R.M.; Koeleman, B.P.; Koster, T.; Rosendaal, F.R.; Dirven, R.J.; de Ronde, H.; van der Velden, P.A.; Reitsma, P.H. Mutation in blood coagulation factor $V$ associated with resistance to activated protein C. Nature 1994, 369, 64-67. [CrossRef]

32. Dahlback, B.; Carlsson, M.; Svensson, P.J. Familial thrombophilia due to a previously unrecognized mechanism characterized by poor anticoagulant response to activated protein C: Prediction of a cofactor to activated protein C. Proc. Natl. Acad. Sci. USA 1993, 90, 1004-1008. [CrossRef] [PubMed]

33. Lunghi, B.; Iacoviello, L.; Gemmati, D.; Dilasio, M.G.; Castoldi, E.; Pinotti, M.; Castaman, G.; Redaelli, R.; Mariani, G.; Marchetti, G.; et al. Detection of new polymorphic markers in the factor V gene: Association with factor V levels in plasma. Thromb. Haemost. 1996, 75, 45-48. [CrossRef] [PubMed]

34. Bernardi, F.; Faioni, E.M.; Castoldi, E.; Lunghi, B.; Castaman, G.; Sacchi, E.; Mannucci, P.M. A factor V genetic component differing from factor V R506Q contributes to the activated protein C resistance phenotype. Blood 1997, 90, 1552-1557. [CrossRef] [PubMed]

35. Castoldi, E.; Lunghi, B.; Mingozzi, F.; Muleo, G.; Redaelli, R.; Mariani, G.; Bernardi, F. A missense mutation (Y1702C) in the coagulation factor $\mathrm{V}$ gene is a frequent cause of factor $\mathrm{V}$ deficiency in the Italian population. Haematologica 2001, 86, 629-633. [PubMed]

36. Simioni, P.; Scudeller, A.; Radossi, P.; Gavasso, S.; Girolami, B.; Tormene, D.; Girolami, A. Pseudo homozygous activated protein $\mathrm{C}$ resistance due to double heterozygous factor $\mathrm{V}$ defects (factor $\mathrm{V}$ Leiden mutation and type I quantitative factor $\mathrm{V}$ defect) associated with thrombosis: Report of two cases belonging to two unrelated kindreds. Thromb. Haemost. 1996, 75, 422-426. [CrossRef] [PubMed]

37. Vos, H.L. Inherited defects of coagulation Factor V: The thrombotic side. J. Thromb. Haemost. 2006, 4, 35-40. [CrossRef] [PubMed]

38. Paraboschi, E.M.; Menegatti, M.; Rimoldi, V.; Borhany, M.; Abdelwahab, M.; Gemmati, D.; Peyvandi, F.; Duga, S.; Asselta, R. Profiling the mutational landscape of coagulation factor V deficiency. Haematologica 2020, 105, e180-e185. [CrossRef]

39. Le, W.; Yu, J.D.; Lu, L.; Tao, R.; You, B.; Cai, X.; Cao, W.J.; Huang, W.; He, R.M.; Zhu, D.L.; et al. Association of the R485K polymorphism of the factor $\mathrm{V}$ gene with poor response to activated protein $\mathrm{C}$ and increased risk of coronary artery disease in the Chinese population. Clin. Genet. 2000, 57, 296-303. [CrossRef] 
40. Tamura, S.; Hashimoto, E.; Suzuki, N.; Kakihara, M.; Odaira, K.; Hattori, Y.; Tokoro, M.; Suzuki, S.; Takagi, A.; Katsumi, A.; et al. Molecular basis of SERPINC1 mutations in Japanese patients with antithrombin deficiency. Thromb. Res. 2019, 178, 159-170. [CrossRef]

41. de Haan, H.G.; Bezemer, I.D.; Doggen, C.J.; Le Cessie, S.; Reitsma, P.H.; Arellano, A.R.; Tong, C.H.; Devlin, J.J.; Bare, L.A.; Rosendaal, F.R.; et al. Multiple SNP testing improves risk prediction of first venous thrombosis. Blood 2012, 120, 656-663. [CrossRef] [PubMed]

42. Ni, H.; Waye, J.S.; Sheffield, W.P.; Eng, B.; Blajchman, M.A. Genetic linkage studies in antithrombin-deficient kindreds using a highly polymorphic trinucleotide short tandem repeat (STR) within the human antithrombin gene. Am. J. Hematol. 1994, 46, 107-111. [CrossRef]

43. Castoldi, E.; Lunghi, B.; Mingozzi, F.; Simioni, P.; Girolami, A.; Bernardi, F. A highly polymorphic microsatellite in the factor V gene is an informative tool for the study of factor V-related disorders. Br. J. Haematol. 2001, 114, 868-870. [CrossRef] [PubMed]

44. Mingozzi, F.; Legnani, C.; Lunghi, B.; Scanavini, D.; Castoldi, E.; Palareti, G.; Marchetti, G.; Bernardi, F. A FV multiallelic marker detects genetic components of APC resistance contributing to venous thromboembolism in FV Leiden carriers. Thromb. Haemost. 2003, 89, 983-989. [PubMed]

45. Quaranta, M.; Erez, O.; Mastrolia, S.A.; Koifman, A.; Leron, E.; Eshkoli, T.; Mazor, M.; Holcberg, G. The physiologic and therapeutic role of heparin in implantation and placentation. Peer. J. 2015, 3, e691. [CrossRef]

46. van Boven, H.H.; Vandenbroucke, J.P.; Briet, E.; Rosendaal, F.R. Gene-gene and gene-environment interactions determine risk of thrombosis in families with inherited antithrombin deficiency. Blood 1999, 94, 2590-2594. [CrossRef] [PubMed]

47. Dahm, A.E.; Bezemer, I.D.; Bergrem, A.; Jacobsen, A.F.; Jacobsen, E.M.; Skretting, G.; Rosendaal, F.R.; Sandset, P.M. Candidate gene polymorphisms and the risk for pregnancy-related venous thrombosis. Br. J. Haematol. 2012, 157, 753-761. [CrossRef] [PubMed]

48. Koster, T.; Rosendaal, F.R.; de Ronde, H.; Briet, E.; Vandenbroucke, J.P.; Bertina, R.M. Venous thrombosis due to poor anticoagulant response to activated protein C: Leiden Thrombophilia Study. Lancet 1993, 342, 1503-1506. [CrossRef]

49. Blom, J.W.; Doggen, C.J.; Osanto, S.; Rosendaal, F.R. Malignancies, prothrombotic mutations, and the risk of venous thrombosis. JAMA 2005, 293, 715-722. [CrossRef]

50. Shi, X.; Xie, X.; Jia, Y.; Li, S. Maternal genetic polymorphisms and unexplained recurrent miscarriage: A systematic review and meta-analysis. Clin. Genet. 2017, 91, 265-284. [CrossRef]

51. Loizidou, E.M.; Kucherenko, A.; Tatarskyy, P.; Chernushyn, S.; Livshyts, G.; Gulkovskyi, R.; Vorobiova, I.; Antipkin, Y.; Gorodna, O.; Kaakinen, M.A.; et al. Risk of Recurrent Pregnancy Loss in the Ukrainian Population Using a Combined Effect of Genetic Variants: A Case-Control Study. Genes 2021, 12, 64. [CrossRef]

52. Houlihan, L.M.; Davies, G.; Tenesa, A.; Harris, S.E.; Luciano, M.; Gow, A.J.; McGhee, K.A.; Liewald, D.C.; Porteous, D.J.; Starr, J.M.; et al. Common variants of large effect in F12, KNG1, and HRG are associated with activated partial thromboplastin time. Am. J. Hum. Genet. 2010, 86, 626-631. [CrossRef]

53. Li, Y.; Bezemer, I.D.; Rowland, C.M.; Tong, C.H.; Arellano, A.R.; Catanese, J.J.; Devlin, J.J.; Reitsma, P.H.; Bare, L.A.; Rosendaal, F.R. Genetic variants associated with deep vein thrombosis: The F11 locus. J. Thromb. Haemost. 2009, 7, 1802-1808. [CrossRef] [PubMed]

54. Morange, P.E.; Oudot-Mellakh, T.; Cohen, W.; Germain, M.; Saut, N.; Antoni, G.; Alessi, M.C.; Bertrand, M.; Dupuy, A.M.; Letenneur, L.; et al. KNG1 Ile581Thr and susceptibility to venous thrombosis. Blood 2011, 117, 3692-3694. [CrossRef] [PubMed]

55. Schmaier, A.H.; Mc Crae, K.R. The plasma kallikrein-kinin system: Its evolution from contact activation. J. Thromb. Haemost. 2007, 5, 2323-2329. [CrossRef]

56. Sugi, T.; Makino, T. Factor XII, kininogen and plasma prekallikrein in abnormal pregnancies. Curr. Drug Targets 2005, 6, 551-557. [CrossRef] [PubMed]

57. Johnson, C.Y.; Tuite, A.; Morange, P.E.; Tregouet, D.A.; Gagnon, F. The factor XII -4C>T variant and risk of common thrombotic disorders: A HuGE review and meta-analysis of evidence from observational studies. Am. J. Epidemiol. 2011, 173, 136-144. [CrossRef]

58. Wei, L.K.; Griffiths, L.R.; Kooi, C.W.; Irene, L. Meta-Analysis of Factor V, Factor VII, Factor XII, and Factor XIII-A Gene Polymorphisms and Ischemic Stroke. Medicina 2019, 55, 101. [CrossRef]

59. Ibrahim-Kosta, M.; Suchon, P.; Couturaud, F.; Smadja, D.; Olaso, R.; Germain, M.; Saut, N.; Goumidi, L.; Derbois, C.; Thibord, F.; et al. Minor allele of the factor V K858R variant protects from venous thrombosis only in non-carriers of factor V Leiden mutation. Sci. Rep. 2019, 9, 3750. [CrossRef] [PubMed]

60. Gorbe, E.; Nagy, B.; Varadi, V.; Kiss, E.; Mattyus, I.; Rigo, J., Jr.; Papp, Z. Mutation in the factor V gene associated with inferior vena cava thrombosis in newborns. Clin. Genet. 1999, 55, 65-66. [CrossRef]

61. Kostka, H.; Siegert, G.; Schwarz, T.; Gehrisch, S.; Kuhlisch, E.; Schellong, S.; Jaross, W. Frequency of polymorphisms in the B-domain of factor V gene in APC-resistant patients. Thromb. Res. 2000, 99, 539-547. [CrossRef]

62. Gemmati, D.; Tognazzo, S.; Catozzi, L.; Federici, F.; De Palma, M.; Gianesini, S.; Scapoli, G.L.; De Mattei, M.; Liboni, A.; Zamboni, P. Influence of gene polymorphisms in ulcer healing process after superficial venous surgery. J. Vasc. Surg. 2006, 44, 554-562. [CrossRef] [PubMed]

63. Tognazzo, S.; Gemmati, D.; Palazzo, A.; Catozzi, L.; Carandina, S.; Legnaro, A.; Tacconi, G.; Scapoli, G.L.; Zamboni, P. Prognostic role of factor XIII gene variants in nonhealing venous leg ulcers. J. Vasc. Surg. 2006, 44, 815-819. [CrossRef] 
64. Ansani, L.; Marchesini, J.; Pestelli, G.; Luisi, G.A.; Scillitani, G.; Longo, G.; Milani, D.; Serino, M.L.; Tisato, V.; Gemmati, D. F13A1 Gene Variant (V34L) and Residual Circulating FXIIIA Levels Predict Short- and Long-Term Mortality in Acute Myocardial Infarction after Coronary Angioplasty. Int. J. Mol. Sci. 2018, 19, 2766. [CrossRef] [PubMed]

65. Gemmati, D.; Zeri, G.; Orioli, E.; Mari, R.; Moratelli, S.; Vigliano, M.; Marchesini, J.; Grossi, M.E.; Pecoraro, A.; Cuneo, A.; et al. Factor XIII-A dynamics in acute myocardial infarction: A novel prognostic biomarker? Thromb. Haemost. 2015, 114, 123-132. [CrossRef]

66. Agostinis, C.; Bulla, R.; Tisato, V.; De Seta, F.; Alberico, S.; Secchiero, P.; Zauli, G. Soluble TRAIL is elevated in recurrent miscarriage and inhibits the in vitro adhesion and migration of HTR8 trophoblastic cells. Hum. Reprod. 2012, 27, 2941-2947. [CrossRef] [PubMed] 